\title{
Pengaruh jumlah haluan pipa paralel pada kolektor surya plat datar absorber batu kerikil terhadap laju perpindahan panas
}

\section{Wirawan*, R. Kurniawan, Mirmanto}

Teknik Mesin Fakultas Teknik Universitas Mataram, Jln. Majapahit No. 62 Mataram Nusa Tenggara Barat Kode Pos : 83125, Telp. (0370) 636087; 636126; ext 128 Fax (0370) 636087.

*Email: wwiralo@yahoo.ac.id

\section{ARTICLE INFO}

Article History:

Received 14 September 2016

Accepted 15 November 2016

Available online 30 December 2016

Keywords:

Solar collector

Absorber

Renewable energy

Collector performance

\begin{abstract}
Recently the use of energy increases. It leads to the energy crisis. Therefore, it is important to promote alternative energy (renewable energy). One of renewable energies, which is potential in Indonesia, is solar enrgy. Solar energy can be harvested using a solar collector. This device can collect or absorb solar radiation and convert it to thermal energy. In this study, two identical collectors are used. One collector consists of 7 pipes and the other comprises 9 pipes. The overall dimension of the collector is $100 \mathrm{~cm} \times 80 \mathrm{~cm} \times 10 \mathrm{~cm}$ and the absorber of the collector is made of gravels with a mesh size of $9.5-12.5 \mathrm{~mm}$. The collectors are placed with a slope of $15^{\circ}$ facing to North. The volumetric rates of water used in the experiments are $300 \mathrm{cc} / \mathrm{min}, 350 \mathrm{cc} /$ $\mathrm{min}$ and $400 \mathrm{cc} / \mathrm{min}$. The results show that the collector with 9 pipes is better than that with 7 pipes.
\end{abstract}

\section{PENDAHULUAN}

Minyak bumi merupakan energi fosil yang saat ini masih menjadi sumber utama untuk memenuhi kebutuhan energi dunia khususnya indonesia. Padahal apabila energi ini digunakan secara terus menerus maka akan habis karena ketersediaanya sangat terbatas dan terus menipis. Upaya - upaya pencarian sumber energi alternatif sebagai pengganti energi fosil menyemangati para peneliti di berbagai negara untuk mencari energi lain yang dikenal sekarang dengan istilah energi terbarukan (renewable energy). Energi terbarukan dapat didefinisikan sebagai energi yang sangat cepat dapat diproduksi kembali melalui proses alam.

Indonesia terkenal sebagai negara yang kaya dengan potensi sumber daya alamnya terutama energi, baik yang berasal dari hasil tambang, air, udara dan matahari. Khusus untuk energi yang memanfaatkan radiasi matahari atau yang sering dikenal dengan energi surya. Energi ini di Indonesia sangat berpotensi karena indonesia sendiri adalah negara yang terletak digaris khatulistiwa dimana matahari bersinar sepanjang tahun. Indonesia merupakan negara yang memiliki intensitas matahari yang berlimpah, yaitu rata-rata $4,8 \mathrm{kWh} / \mathrm{m}^{2}$ (Efendi dkk, 2015).

Kolektor surya adalah sistem pengumpul radiasi surya yang dikonversikan dalam bentuk panas oleh absorber. Panjang gelombang radiasi surya yang dapat diserap adalah $0,29-2,5 \mu \mathrm{m}$ (Rosa, 2007).

Hasil penelitian Saputra (2015) terhadap jumlah pipa pada kolektor surya plat datar dengan absorber batu granit memperlihatkan bahwa jumlah pipa sangat berpengaruh terhadap laju perpindahan panas pada kolektor. Jumlah pipa yang lebih banyak (pada penelitian ini) memiliki 
luasan perpindahan panas yang besar. Sehingga laju perpindahan kalor pada jumlah pipa 7 lebih besar dari pada jumlah pipa 5. Energi yang digunakan $Q_{u s e}$ pada penelitian ini yang paling tinggi terjadi pada jam 13.00 dengan debit 300 $\mathrm{cc} / \mathrm{min}$ pada pipa haluan 7 sebesar 600 Watt.

Pada penelitian Wilis dan Santosa (2014) yang berjudul "Variasi Sudut Kemiringan Kolektor Surya Solar Water Heater" tentang pengaruh variasi sudut kemiringan pada kolektor surya dengan variasi $20^{\circ}$ dan $15^{\circ}$ terhadap efisiensi kolektor surya pelat datar. Menunjukkan bahwa efisiensi tertinggi adalah pada waktu alat di setting pada kemiringan $15^{\circ}$, pada kelembaban udara, diambil pada jam 12.00-13.00 WIB yaitu sebesar $85,14 \%$.

Hasil penelitian Asri (2015) tentang pengaruh penggunaan absorber batu krikil dengan ukuran mesh 4,75-6,3 mm, dan batu kerikil dengan ukuran mesh 9,5-12,5 mm pada kolektor surya pelat datar. Menunjukan bahwa penggunaan batu kerikil ukuran mesh 9,5-12,5 mm sebagai absorber lebih bagus dalam menyerap kalor dibandingkan dengan batu kerikil dengan ukuran mesh 4,75-6,3 $\mathrm{mm}$.

Energi yang masuk didalam kolektor dapat didefinisikan sebagai besarnya intensitas radiasi matahari dikalikan dengan besarnya luasan yang terkena intensitas radiasi matahari tersebut.
Sehingga kalor yang diterima oleh kolektor dapat dirumuskan sebagai berikut, Holman (1998):

$$
Q_{\text {in }}=I_{T} A_{c}
$$

dengan $Q_{\text {in }}$ adalah laju aliran kalor yang masuk kolektor $(\mathrm{W}), I_{T}$ adalah intensitas radiasi matahari $\left(\mathrm{W} / \mathrm{m}^{2}\right)$ dan $A_{c}$ adalah luasan kolektor $\left(\mathrm{m}^{2}\right)$.

Panas yang diserap oleh air, $Q_{u s e}$, di dalam kolektor adalah merupakan fungsi laju aliran massa, kapasitas panas air pada tekanan konstan, $T_{i}$ dan $T_{o}$. $T_{i}$ dan $T_{0}$ adalah suhu air masuk dan suhu air keluar $\left({ }^{\circ} \mathrm{C}\right)$. $Q_{u s e}$ dapat diestimasi sebagai berikut (Holman, 1998):

$$
Q_{u s e}=\dot{m} c_{p}\left(T_{o}-T_{i}\right)
$$

dimana $\dot{m}$ adalah laju aliran massa $(\mathrm{kg} / \mathrm{s}), c_{p}$ adalah panas jenis air $(\mathrm{J} / \mathrm{kg} \mathrm{K})$. Radiasi matahari yang mengenai permukaan kolektor, sebagian besar akan diserap dan dihantarkan ke fluida dan merupakan energi yang digunakan. Namun dalam berbagai sistem, maka akan terjadi kerugian energi. Besarnya kerugian energi $\left(Q_{\text {loss }}\right)$ dalam kolektor surya merupakan selisih antara energi yang masuk dalam kolektor $\left(Q_{i n}\right)$ dengan kalor yang diserap oleh air $\left(Q_{u s e}\right)$. Kerugian energi dari kolektor dituliskan sebagai, (Holman, 1998):

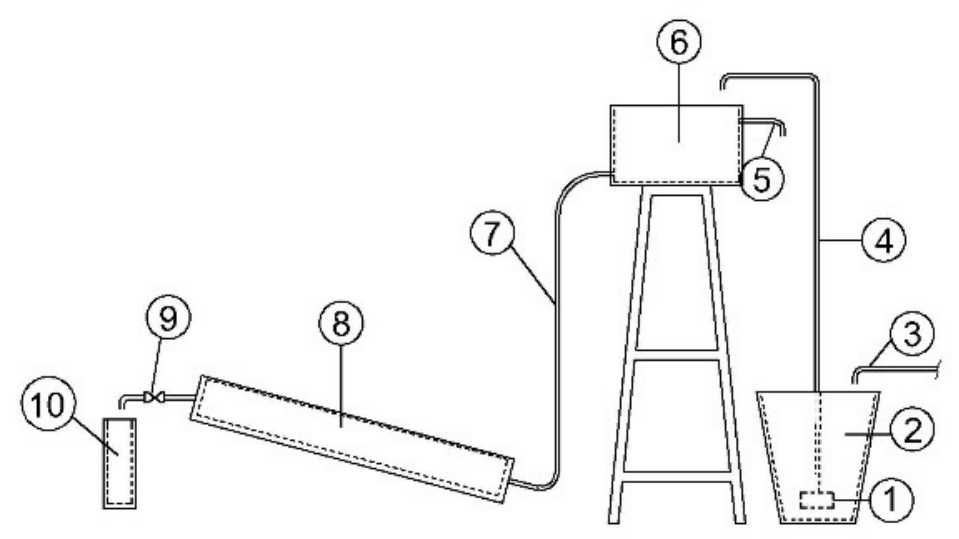

1. Pompa, 2. Bak plastik penampung sumber air , 3. Selang sumber air, 4. Pipa, 5. Pipa overflow, 6. Bak penampung air, 7. Selang, 8. Kolektor surya, 9. Keran, 10. Gelas ukur 
$Q_{\text {loss }}=Q_{\text {in }}-Q_{\text {use }}$

Efisiensi kolektor, $\eta$, dapat didefinisikan sebagai perbandingan antara daya berguna kolektor dengan daya radiasi matahari yang datang (Syamsu dkk, 2012) dan diprediksi dengan persamaan:

$\eta=\frac{Q_{u s e}}{Q_{\text {in }}}$

\section{METODE PENELITIAN}

Metode yang digunakan adalah eksperimen dengan menggunakan alat-alat seperti termokopel, kompas, alat baca termokopel, gelas ukur dan stopwatch, anemometer, pyranometer atau solarmeter. Skema alat penelitian dapat dilihat pada gambar 1, sedangkan foto kolektor surya yang digunakan disajikan pada gambar 2 .

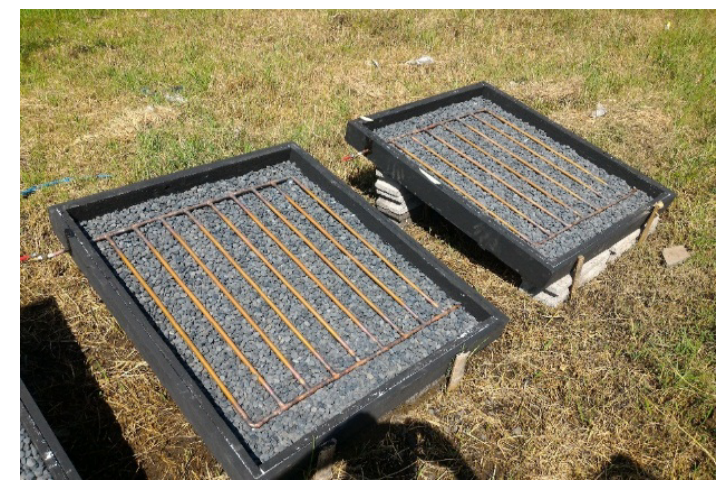

Gambar 2. Kolektor matahari 7 haluan dan 9 haluan

Mula-mula air dialirkan dari kran menuju bak bawah. Dari bak bawah air dialirkan ke bak atas dengan menggunakan pompa. Untuk menjaga permukaan air di bak atas tetap maka diberi over flow. Selanjutnya air mengalir dari bak atas menuju kolektor secara alami akibat adanya gravitasi bumi. Pada sisi masuk dan keluar kolektor diberi termokopel untuk mengukur suhu air pada bagianbagian tersebut. Air keluar dari kolektor diukur dengan menggunakan gelas ukur dan stop watch. Akhirnya air dibuang ke lingkungan.

\section{Pengujian}

Sebelum memulai pengujian terlebih dahulu mempersiapkan alat penelitian dan alat ukur kemudaian mengecek kondisi alat penelitian dan alat ukur tersebut, mengkalibrasi alat ukur yang perlu dikalibrasi, setelah itu melakukan pemasangan alat ukur pada kolektor surya. Pengujian dilakukan mulai pukul 10.00-18.00 Wita atau sampai $T i=T o$ dalam kondisi cuaca cerah dengan prosedur sebagai berikut :

1. Meletakkan 2 buah kolektor surya di bawah sinar matahari dan memposisikan kolektor surya sesuai dengan arah matahari.

2. Mengatur sudut kemiringan kolektor surya sebesar $15^{\circ}$

3. Mengatur debit air sebesar $300 \mathrm{cc} /$ menit, pada kedua kolektor 7 haluan dan 9 haluan.

4. Melakukan pengukuran temperatur lingkungan, permukaan kaca, temperatur absorber, temperatur air masuk dan keluar pada masingmasing kolektor.

5. Pencatatan suhu lingkungan, permukaan kaca, suhu absorber, temperatur air masuk dan keluar yang dilakukan dari jam 10.00 hingga 18.00 WITA (Tin=Tout).

6. Pengambilan data dilakukan setiap 15 menit.

7. Mengulang langkah pengujian untuk debit 350 $\mathrm{cc} /$ menit dan $400 \mathrm{cc} /$ menit pada hari berikutnya pada jam yang sama dengan menggunakan kolektor yang sama.

8. Masing-masing variasi debit diuji sebanyak tiga kali, sehingga total waktu pengujian adalah sembilan hari.

\section{HASIL DAN PEMBAHASAN}

Untuk mengamati besarnya kalor yang digunakan $\left(q_{\text {use }}\right)$ pada kolektor surya 9 haluan dan 7 haluan dengan variasi debit $300 \mathrm{cc} / \mathrm{min}, 350$ $\mathrm{cc} / \mathrm{min}$, dan $400 \mathrm{cc} / \mathrm{min}$ terhadap waktu pengamatan, maka disajikan grafik hubungan kenaikan temperatur dengan waktu pengamatan untuk masing-masing kolektor seperti pada gambar 3, gambar 4, gambar 5 di bawah ini.

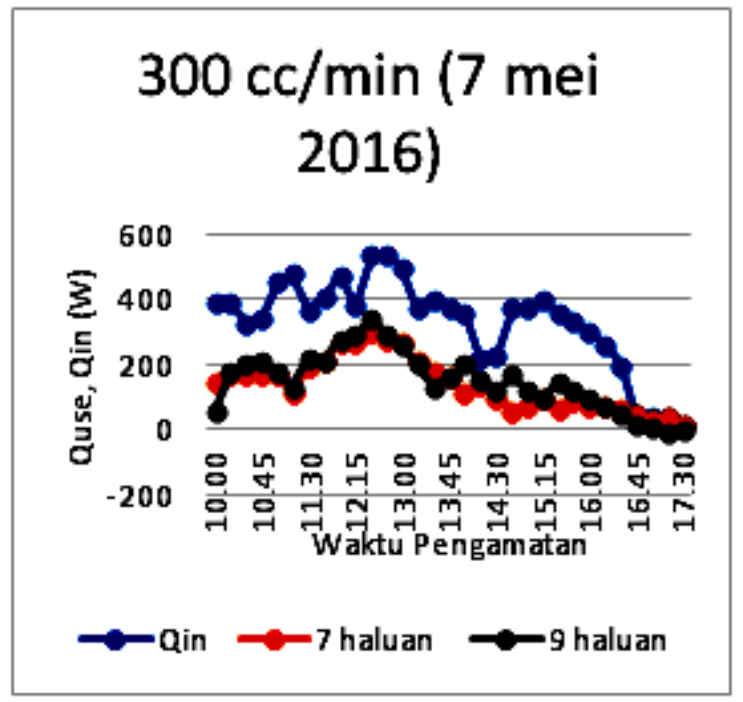

Gambar 3. Hubungan antara kalor yang digunakan terhadap waktu pengamatan untuk debit 300 $\mathrm{cc} / \mathrm{min}$ 


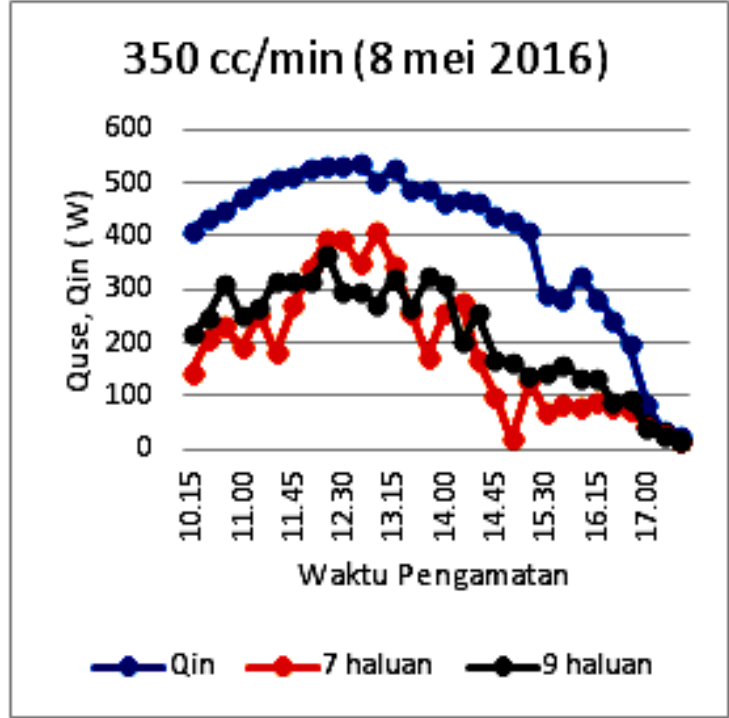

Gambar 4. Hubungan antara kalor yang digunakan terhadap waktu pengamatan untuk debit 350 $\mathrm{cc} / \mathrm{min}$

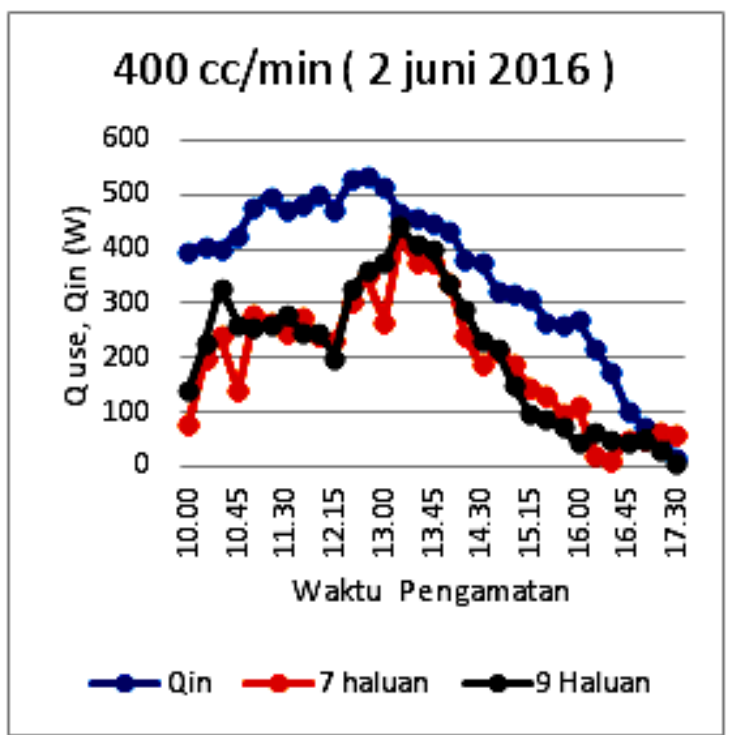

Gambar 5. Hubungan antara kalor yang digunakan terhadap waktu pengamatan untuk debit 400 $\mathrm{cc} / \mathrm{min}$

Pada gambar 3, gambar 4, gambar 5, terlihat bahwa kalor yang digunakan pada kolektor 9 haluan lebih besar dari pada kolektor 7 haluan, ini terjadi karena pengaruh jumlah pipa, dimana jumlah pipa ini mempengaruhi luasan perpindahan panas. Pada kolektor 9 haluan, luasan perpindahan panasnya lebih besar dibandingkan dengan kolektor 7 haluan. Oleh sebab itu kalor yang diserap oleh air pada kolektor 9 haluan lebih besar.
Pada ketiga gambar tersebut juga dapat dilihat kalor yang digunakan $\left(Q_{u s e}\right)$ semakin meningkat seiring bertambahnya waktu pengamatan, akan tetapi kembali turun setelah melewati waktu intensitas tertinggi. Hal ini disebabkan karena semakin siang jam pengamatan, maka radiasi matahari semakin tinggi, sehingga kalor yang diserap oleh absorber semakin tinggi dan demikian pula kalor yang digunakan untuk memanaskan air semakin tinggi.

Hubungan antara kerugian kalor $\left(Q_{\text {loss }}\right)$ untuk kolektor 7 haluan dan 9 haluan pada debit yang sama terhadap waktu pengamatan disajikan pada gambar 6, gambar 7, dan gambar 8 di bawah ini.

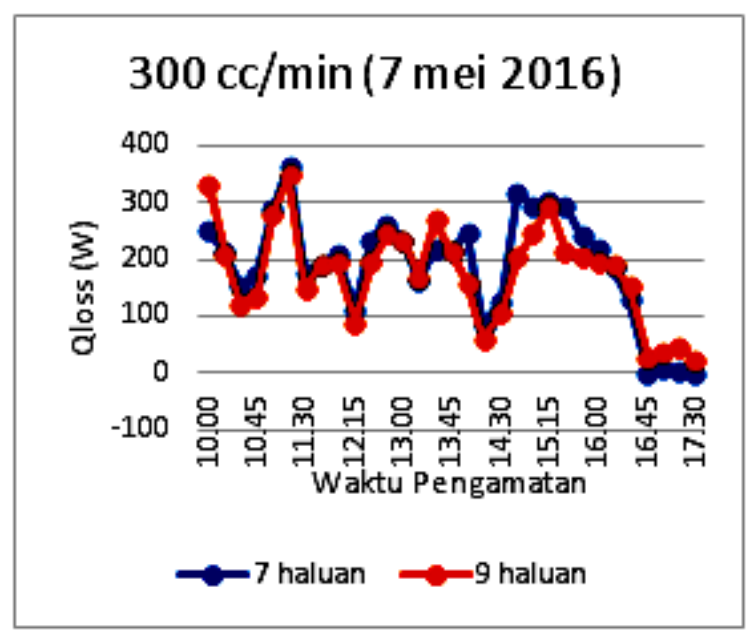

Gambar 6. Hubungan antara kerugian kalor $\left(Q_{\text {loss }}\right)$ terhadap waktu pengamatan untuk debit 300 $\mathrm{cc} / \mathrm{min}$

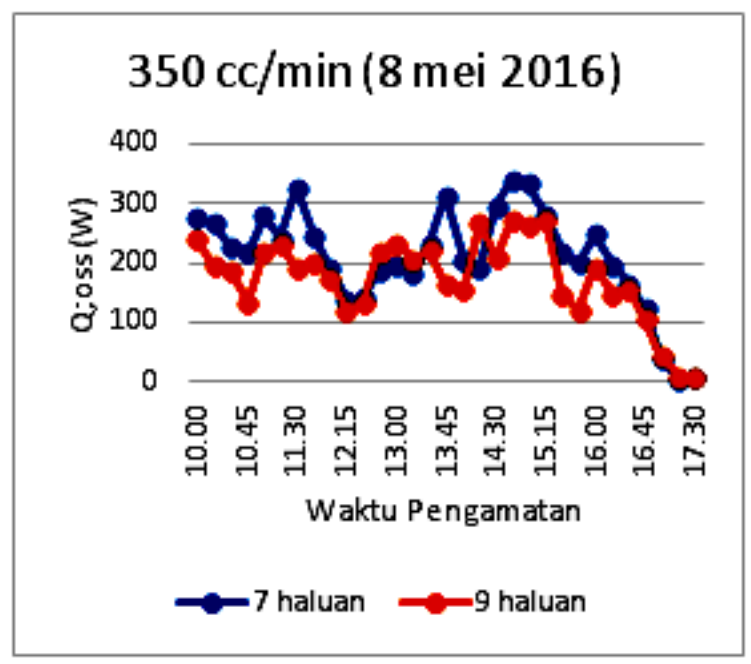

Gambar 7. Hubungan antara kerugian kalor $\left(Q_{\text {loss }}\right)$ terhadap waktu pengamatan untuk debit 350 $\mathrm{cc} / \mathrm{min}$ 


\section{$400 \mathrm{cc} / \mathrm{min}$ ( 2 Juni 2016 )}

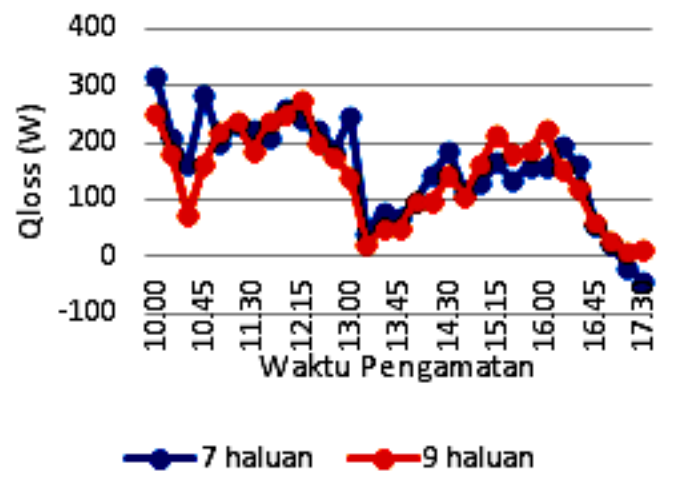

Gambar 8. Hubungan antara kerugian kalor $\left(Q_{\text {loss }}\right)$ terhadap waktu pengamatan untuk debit 400 $\mathrm{cc} / \mathrm{min}$

Pada gambar 6-8 di atas terlihat bahwa kerugian kalor cenderung konstan seiring dengan tambahnya jam pengamatan terutama sebelum jam 15.00 Wita. Sedangkan setelah jam 15.00 Wita rata-rata untuk berbagai debit, kerugian kalornya turun. Hal ini disebabkan karena semakin lama waktu pengamatan (terutama setelah jam 15.00 Wita), $Q_{\text {use }}$ nya masih tinggi akibat adanya kalor yang tersimpan. Sementara itu, intensitas matahari mulai turun sehingga dengan menngunakan persamaan (3), kerugian kalornya turun. Tetapi seandainya kerugian kalor dicari berdasarkan suhu absorber maka kerugian kalornya masih tetap tinggi, karena suhu absorber masih tinggi akibat dari kalor yang tersimpan pada kerikil. Pada gambar 6, gambar 7 dan gambar 8 kerugian kalornya berfluktuasi paling besar. Ini disebabkan oleh intensitas radiasi matahari yang tidak konstan. Dari ketiga gambar juga dapat dilihat bahwa kerugian kalor untuk kolektor 7 haluan pada setiap debit lebih besar dibandingakan kolektor 9 haluan. Fenomena ini disebabkan oleh fakta bahwa kolektor 9 lebih banyak dalam memindahkan kalor ke air karena pengaruh luas permukaan pipa yang lebih besar. Jumlah pipa haluan 7 juga pernah diteliti oleh Wirawan dkk (2015), tetapi mereka menyimpulkan bahwa jumlah 7 merupakan kolektor yang paling bai. Jadi semakin banyak jumlah haluan semakin banyak mentransfer panas ke fluida kerja.

Hubungan antara efisiensi kolektor $(\eta)$ untuk kolektor 7 haluan dan kolektor 9 haluan pada debit yang sama terhadap waktu pengamatan diberikan pada gambar 9, gambar 10 dan gambar 11 .

Gambar 9-11 menjelaskan hubungan antara efisiensi kolektor untuk masing-masing jumlah haluan pipa pada debit yang berbeda-beda.
Dimana efisiensi adalah perbandingan antara kalor yang digunakan untuk memanaskan air dengan kalor yang diterima kolektor. Namun kalor yang masuk pada kolektor tidak serta merta digunakan oleh kolektor untuk memanaskan air, ada sebagian kalor yang hilang kelingkungan. Efisiensi kolektor 9 haluan lebih besar dibandingkan 7 haluan, ini disebabkan karena kalor yang diserap air pada kolektor 9 haluan lebih banyak dibandingkan pada kolektor 7 haluan, lihat gambar 3 , gambar 4 dan gambar 5 .

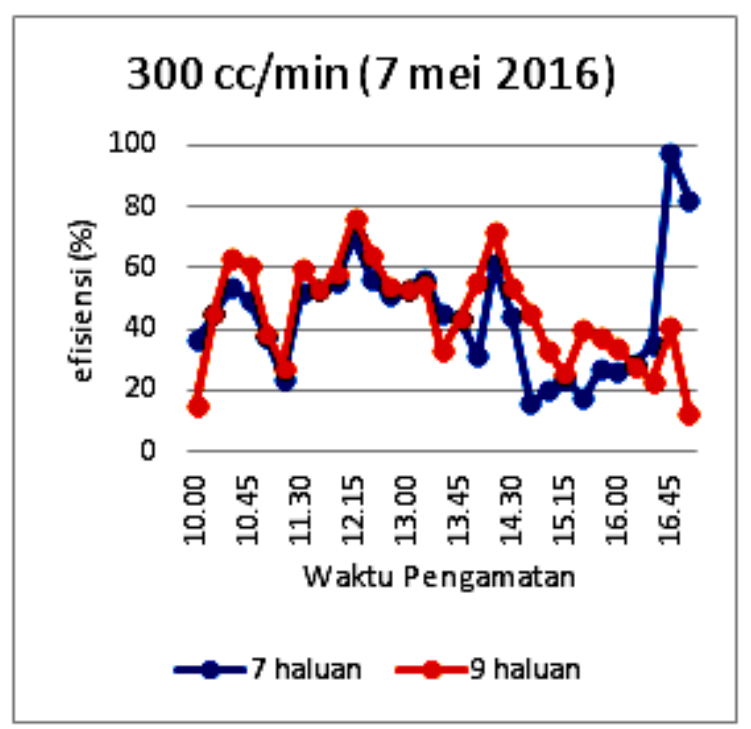

Gambar 9. Hubungan efisiensi kolektor $(\eta)$ terhadap waktu pengamatan untuk debit 300 $\mathrm{cc} / \mathrm{min}$

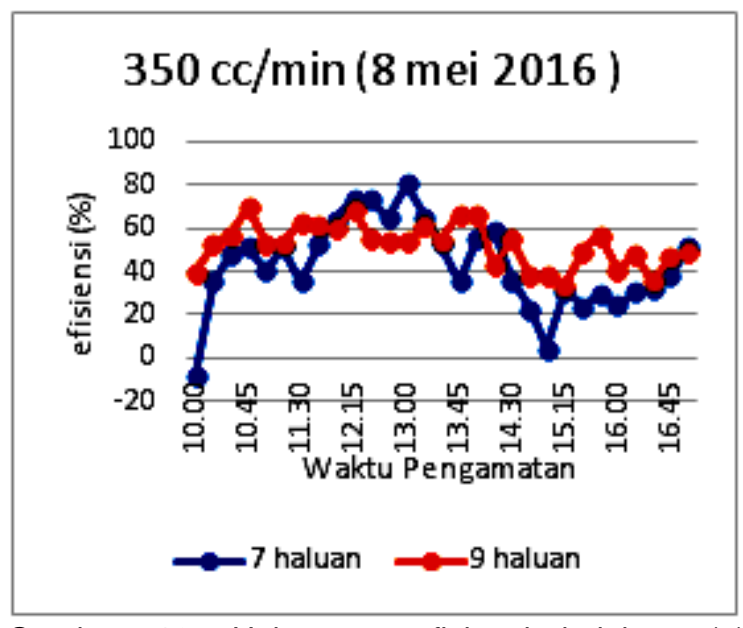

Gambar 10. Hubungan efisiensi kolektor $(\eta)$ terhadap waktu pengamatan untuk debit 350 $\mathrm{cc} / \mathrm{min}$

Pada gambar 9, gambar 10 dan gambar 11 juga terlihat ada nilai efisiensi yang mencapai 100\% 
padahal pada waktu tersebut nilai intensitas radiasi matahari kecil. Hal demikian ini disebabkan oleh nilai $Q_{\text {in }}$ untuk memanaskan air tidak semata-mata dari intensitas matahari tetapi juga dari batu kerikil, karena batu memiliki kemampuan menyimpan panas. Sedangkan pada penelitian ini hanya menganalisa pengaruh kalor yang masuk dari intensitas mataharai terhadap efisiensi dan kerugian kalor $\left(Q_{\text {loss }}\right)$. Oleh sebab itu nilai $Q_{\text {loss }}$ negatif (-) dihitung dengan menggunakan persamaan (3). Sehingga pada waktu intensitas kecil energi yang digunakan untuk memanaskan air lebih besar dibandingkan dengan energi yang masuk.

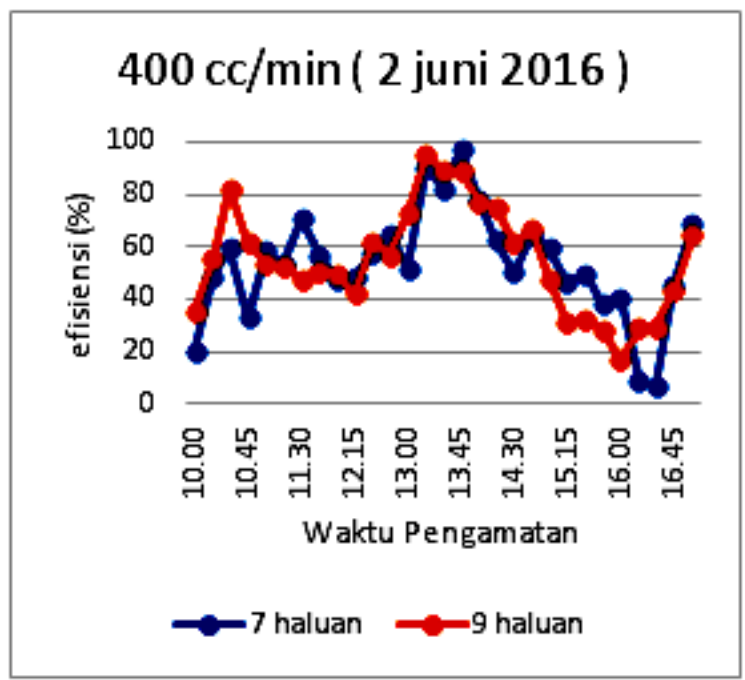

Gambar 11. Hubungan efisiensi kolektor $(\eta)$ terhadap waktu pengamatan untuk debit 400 $\mathrm{cc} / \mathrm{min}$

\section{KESIMPULAN}

Berdasarakan hasil penelitian, kemudian melakukan analisa data dan pembahasan dapat ditarik kesimpulan sebagai berikut :

1. Koletktor 9 haluan lebih bagus dalam laju perpindahan panas dibandingkan dengan kolektor 7 haluan hal ini membuktikan bahwa ada pengaruh jumlah haluan pipa terhadap laju perpindahan panas, hal ini disebabkan karena semakin banyak haluan pipa maka luasan pernukaan pipa akan semakin besar.

2. Waktu Pengamatan mempengaruhi laju perpindahan panas. Puncaknya pada pukul 12.00-13:30 WITA.

3. Debit yang divariasikan $300 \mathrm{cc} / \mathrm{min}, 350 \mathrm{cc} / \mathrm{min}$ dan $400 \mathrm{cc} / \mathrm{min}$ memiliki pengaruh terhadap laju perpindahan panas, semakin tinggi debit nilai perpindahan panasnya semakin tinggi akan tetapi kembali turun pada debit $400 \mathrm{cc} / \mathrm{min}$.

\section{UCAPAN TERIMAKASIH}

Penulis pada kesempatan ini mengucakan terimakasih kepada semua pihak yang membantu baik berupa materi maupun pikiran sehingga penelitian dan paper ini dapat terselesaikan. Yang kedua penulis mengucapkan terimakasih kepada Kemenristek atas bantuan dana penelitian melalui program penelitian Hibah Bersaing tahun 2016. Yang ke tiga penulis mengapresiasi Jurusan Teknik Mesin atas fasilitas yang dipergunakan dalam penelitian ini.

\section{DAFTAR NOTASI}

$A_{a b s}=$ Luas absorber $\left(\mathrm{m}^{2}\right)$

$\mathrm{A}_{\mathrm{c}} \quad=$ Luas kolektor $\left(\mathrm{m}^{2}\right)$

$\mathrm{A}_{\mathrm{g}} \quad=$ Luas kaca $\left(\mathrm{m}^{2}\right)$

$\mathrm{C}_{\mathrm{p}} \quad=$ Kalor spesifik $(\mathrm{J} / \mathrm{kg} . \mathrm{K})$

$\mathrm{Fr} \quad=$ Faktor bentuk

$\mathrm{h}=$ Koefisien konveksi

$\mathrm{I}_{\mathrm{T}} \quad=$ Radiasi matahari $\left(\mathrm{W} / \mathrm{m}^{2}\right)$

$\mathrm{K}=$ Konduktivitas $\left(\mathrm{W} / \mathrm{m}^{2} \mathrm{~K}\right)$

$\mathrm{Q}_{\mathrm{A}} \quad=$ Kerugian kalor atas $(\mathrm{W})$

$\mathrm{Q}_{\mathrm{B}} \quad=$ Kerugian kalor bawah $(\mathrm{W})$

$Q_{S} \quad=$ Kerugian kalor samping (W)

$\mathrm{Q}_{\mathrm{c}} \quad=$ Laju perpindahan panas konveksi (W)

$\mathrm{Q}_{\mathrm{in}} \quad=$ Energi yang masuk pada Kolektor (W)

$\mathrm{Q}_{\mathrm{k}} \quad=$ Laju perpindaham panas konduksi (W)

$\mathrm{Q}_{\text {loss }} \quad=$ Energi yang hilang dari kolektor $(\mathrm{W})$

$\mathrm{Q}_{\mathrm{r}} \quad$ = Laju perpindahan panas radiasi (W)

$\mathrm{Q}_{\text {use }}=$ Energi yang berguna/ energi yang

digunakan untuk memanaskan fluida (W)

$\mathrm{R}_{\text {total }}=$ Resistansi Total (K/W)

$\mathrm{T}_{\mathrm{a}} \quad=$ Temperatur lingkungan luar kolektor $(\mathrm{K})$

$\mathrm{T}_{\text {abs }}=$ Temperatur absorber $(\mathrm{K})$

$\mathrm{T}_{\text {bulk }}=$ Temperatur absorber $(\mathrm{K})$

$\mathrm{T}_{\mathrm{f}} \quad=$ Temperatur fluida $(\mathrm{K})$

$\mathrm{T}_{\mathrm{g}} \quad=$ Temperatur Kaca atas $(\mathrm{K})$

$\mathrm{T}_{\mathrm{gb}} \quad=$ Temperatur kaca bawah $(\mathrm{K})$

$\mathrm{T}_{\mathrm{i}} \quad=$ Temperatur air yang masuk $(\mathrm{K})$

$\mathrm{T}_{\mathrm{O}} \quad=$ Temperatur air yang keluar $(\mathrm{K})$

$\mathrm{T}_{\text {din }} \quad=$ Temperatur dinding $(\mathrm{K})$

= Laju aliran massa $(\mathrm{kg} / \mathrm{s})$

$v \quad=$ Kecepatan angin $(\mathrm{m} / \mathrm{s})$

$\Delta T \quad=$ Perbedaan Temperatur $(\mathrm{K})$

\section{DAFTAR PUSTAKA}

Asri A.B., 2015, Pengaruh penggunaan absorber batu kerikil terhadap laju perpindahan panas pada kolektor surya pelat datar, Tugas Akhir, Universitas Mataram, Mataram.

Holman J. P., 1998; Perpindahan kalor, Penerbit Erlangga, Jakarta.

Rosa Y., 2007, Rancang bangun kolektor pelat datar energi surya untuk sistem pengeringan pasca panen, Jurnal Teknik Mesin, ISSN 1829-8958, Vol. 4, No. 2, Hal. 68-82, Padang. 
Saputra B.H., 2015, Pengaruh jumlah pipa pada kolektor surya absorber batu granit terhadap laju perpindahan panas, Tugas Akhir, Universitas Mataram, Mataram.

Syamsu W, D., Selleng K., Mustofa, 2012, Efektifitas kolektor energi surya pada konfigurasi paralel-serpentine, Majalah IImiah, MEKTEK, No.2, Hal. 12-16, Palu.

Wilis G.R., Santosa I., 2014, Variasi sudut kemiringan kolektor surya solar water heater, Prosiding Seminar Nasional Aplikasi Sains \& Teknologi (SNAST), Yogyakarta, 15 November 2014.

Wirawan M., Mirmanto, Susana I.G.B., Sutanto R., 2015, Pengaruh susunan pipa Ialuan terhadap pemanfaatan kalor pada kolektor surya pelat datar absorber granite, Dinamika Teknik Mesin, Vol. 5, No. 1, 50-55. 